\title{
Polysèmes
}

Revue d'études intertextuelles et intermédiales

\section{Parody and Femininity in British Surrealism (Ithell Colquhoun and Leonora Carrington)}

Parodie et féminité dans le surréalisme britannique d'Ithell Colquhoun et Leonora Carrington

Tifaine Bachet

\section{CpenEdition}

Electronic version

URL: http://journals.openedition.org/polysemes/7671

DOI: 10.4000/polysemes.7671

ISSN: 2496-4212

Publisher

SAIT

Electronic reference

Tifaine Bachet, « Parody and Femininity in British Surrealism (Ithell Colquhoun and Leonora

Carrington) », Polysèmes [Online], 23 | 2020, Online since 30 June 2020, connection on 02 July 2020.

URL : http://journals.openedition.org/polysemes/7671; DOI : https://doi.org/10.4000/polysemes.

7671

This text was automatically generated on 2 July 2020.

Polysèmes 


\title{
Parody and Femininity in British Surrealism (Ithell Colquhoun and Leonora Carrington)
}

\author{
Parodie et féminité dans le surréalisme britannique d'Ithell Colquhoun et
} Leonora Carrington

Tifaine Bachet

1 In the following extract from Leonora Carrington's novel The Hearing Trumpet (1976), the heroine predicts what will come of surrealism in the art world. Through her fictional character, Carrington ironically posits that the avant-garde movement will join the art canon and establishment it initially so violently opposed:

Surrealism is no longer considered modern today and almost every village rectory and girl's school have surrealist pictures hanging on their walls. Even Buckingham Palace has a large reproduction of Magritte's famous slice of ham with an eye peering out. It hangs, I believe, in the throne room. Times do change indeed. The Royal Academy recently gave a retrospective exhibition of Dada art and they decorated the gallery like a public lavatory. In my day people in London would have been shocked. (66)

2 This portrayal is in blatant contrast with the revolution that the surrealists advocated when, in 1924, at the outset of the movement, they positioned themselves in opposition to prevailing realist and bourgeois attitudes. Many surrealist artists, such as René Magritte, Marcel Duchamp, Max Ernst and even André Breton, critically imitated specific texts, paintings, artistic conventions and a certain perception of reality. In their Dictionnaire abrégé du surréalisme, André Breton and Paul Éluard incongruously distorted the traditional dictionary form to create one that was reflective of their movement. With his now famous ready-mades, Duchamp comically reworked and gave a new context to everyday objects. The surrealists thus used parody to define their movement and stance on society. In this paper, British surrealist artists Leonora Carrington and Ithell Colquhoun will be the focus of discussion. As has been sketched out in The Hearing Trumpet, surrealist women artists like Carrington and Colquhoun did not forgo parody but consistently engaged in it. Their versions of it, however, bear a 
different tinge. Through a careful analysis of selected works, my purpose in this essay is to demonstrate that Carrington and Colquhoun subtly parodied the gendered assumptions underlying surrealism.

\section{Colquhoun and Carrington's parodic position within surrealism}

3 Although there is no record of Colquhoun and Carrington ever meeting, numerous parallels can be drawn between the two artists' introduction into and subsequent position within surrealism. Indeed, after receiving a rather formal art education in London, both Colquhoun (Shillitoew 1) and Carrington (Aberth 21-23) joined the surrealist ranks in the 1930s as they recognized the movement's immensely liberating and challenging potential. Surrealism was overarchingly appealing to them as it offered great prospects for female personal and artistic emancipation. The two female artists were given access to an artistic community which exhibited and published their work. They were also able to freely engage in artistic discussion and practice alongside prominent artists. Colquhoun, for example, met and maintained a correspondence with Breton and took part in surrealist theorizing-most notably on automatism. ${ }^{1}$ As for Carrington, after falling in love with Ernst, she became an active member of Breton's circle in Paris. She once reported in an interview that she felt great relief at being taken seriously and not being automatically dismissed or put down on the basis of her gender (Aberth 144).

4 Surrealism also resonated with these women artists as it aimed at revolutionizing human experience. Positioning itself against realism and naturalism, it sought to free the imagination and free men from the control of reason. Psychic automatism was presented as the means of achieving just this. It is described by Breton in the "First Manifesto of Surrealism" as a method, following which the artist, in a hypnagogic state, eliminates conscious thought from the creative process-in other words a way to express the unconscious, that which is not governed by logic and reason:

SURREALISM: psychic automatism in its pure state, by which one proposes to express-verbally, by means of the written word, or in any other manner, the actual

functioning of thought. Dictated by thought, in the absence of any control exercised by reason, exempt from any aesthetic or moral concern. (Breton 328)

5 The revolutionary scope of such a liberation of the unconscious was great, as it had the potential of undermining traditional hierarchies of power or social values. The occultation of surrealism which Breton called for in the "Second Manifesto of Surrealism" also bore that potential. Breton paved the way for the construction of a new world or a new state of awareness, as he hoped to determine the "point of the mind at which life and death, the real and the imagined, past and future, the communicable and the incommunicable, high and low, cease to be perceived as contradictions" (Breton 781).

However, Colquhoun and Carrington soon realised that the position of women within surrealism was ambiguous. Indeed, the surrealist movement valued its female members in so far as they were conducive to men's creative process. The women within surrealism were revered as muses, as "the image of man's inspiration and his salvation" (Chadwick 13), or relegated to positions, such as that of the femme fatale or woman child, that deprived them of any agency or independence from men. ${ }^{2}$ In other words, 
the image of woman-or of "the collective person of the woman", as Breton puts it in Communicating Vessels (87)-as an abstract principle that fuelled men's imagination and art prevailed in surrealism. As indicated in Communicating Vessels, Breton's writings encapsulate that attitude towards women. At times, Breton adopts a discourse which is openly gendered; at other times he relies on an opposition between what is feminine and what is masculine.

7 An illustrative example of this is the exploration of the concepts of love and desire within surrealism, and more specifically Breton's theory of l'amour fou which guided and permeated the group from the mid-1920s onwards. This theory delineates the transformative power of mad and passionate romantic love with the ideal woman. Breton's approach is centred on the metamorphic process that the erotic and irrational qualities of the female initiate in men. Women are presented as irresistible creatures enveloped in sexual and erotic force.

8 We could add to this the treatment of the figure of the androgyne. Victoria Ferentinou, who has extensively worked on the figure of the androgyne within surrealism, remarks that male surrealists read this alchemical symbol of union and resolution of opposites in erotic terms only (Ferentinou 2011, 8-9). She specifically refers to Breton, Ernst and Victor Brauner, who used the androgyne in their artistic practice "as an emblem of a completeness that could be realised through heterosexual copulation", and produced images where the female part was often subordinate to the male part or used as a gateway to the male's own realization (Ferentinou 2011, 9). Therefore, with regards to gender, surrealism did not put into operation a radical revision of patriarchal values.

9 As a result, women artists often struggled to identify with the theoretical side of surrealism (Chadwick 33) and thus existed on the fringes of the movement. This is the case with Colquhoun and Carrington, who worked both within and in parallel to surrealism. This interplay of proximity and opposition is reminiscent of the approach of the parodist according to Linda Hutcheon. Hutcheon gives the following insight into the etymology of "parody":

The textual or discursive nature of parody [...] is clear from the odos part of the word, meaning song. The prefix para has two meanings, only one of which is usually mentioned-that of "counter" or "against". Thus parody becomes an opposition or contrast between texts. [...] However, para in Greek can also mean "beside", and therefore there is a suggestion of an accord or intimacy instead of contrast. (Hutcheon 1991, 32)

Although Hutcheon mainly focuses on the textual aspect of parody, the term "parodic" applies equally well to Colquhoun's and Carrington's positions within the surrealist movement.

Concurrently, Colquhoun and Carrington drew on parody to debunk surrealist female ideals and gendered assumptions. In the next sections, the two artists' approach will be explored and contrasted: the question of whether they engaged in erotic idealisation, or initiated new directions in surrealism will be addressed. In other words, the study of their parodic works will determine whether they also submitted the male to erotic projections and shaped men in terms of their desires. Did they reinforce the erotic and irrational image of the female in surrealism or did they provide alternative images of women? 


\section{Ithell Colquhoun's early parodic paintings}

11 The three paintings which will be brought into focus are controversial works by Colquhoun that were the most frequently exhibited at the time. ${ }^{3}$ They were produced between 1938 and 1940, at the beginning of Colquhoun's association with the surrealist movement, and provide an illustrative example of her firmly ironic stance on surrealism.

12 Painted in 1938, Scylla $a^{4}$ depicts what appears to be a seascape: two ribbed rocks rise from the water in the foreground, separated by a line of reddish seaweed. In the background, a small white boat can be seen approaching. The painting is surrealist in inception and technique. Indeed, when asked by the Tate Gallery to comment on it, Colquhoun answered: "It was suggested by what I could see of myself in a bath [...]. It is [...] a pictorial pun, or double-image in the Daliesque sense-not the result of a dream but of a dreamlike state" (Colquhoun 1988, my emphasis). This comment establishes obvious links with André Breton's psychic automatism and directly references Salvador Dalís double-image as the central method adopted by the artist. According to this method, which Dalí had termed his "paranoiac-critical method", two or more independent images are simultaneously discernible within the same forms. ${ }^{5}$ In the case of Colquhoun's Scylla, the legs and vagina of the woman in her bath respectively transform into rocks and seaweed. Critics have further perceived the two rocks rising from the sea as phallic symbols (Ades 40, Allmer 20, Tate). The rocks/penises meet at the top to form an oval gap which is expressively vaginal. Duality is at the heart of the image and everything (including penis and vagina) is at least doubled.

While she pays tribute to Dalís surrealist technique, Colquhoun also undertakes to parody the prevailing erotic imagery within surrealist art as well as the tendency to depict landscape metaphorically as Woman. This tendency can most notably be seen in André Masson's female earth landscapes of the 1930s and in Man Ray's drawings in which women are incorporated into landscapes (Ades 40). It should also be noted that Colquhoun's Scylla was first shown at the Mayor Gallery in 1939 next to some of Roland Penrose's paintings such as Good Shooting (1938) and Octavia (1939). These works portray passive, fetishized and objectified women's bodies (Shillitoe 227). Using inversion and irony, Colquhoun depicts nature as both female and male. Interestingly, irony is, in a way, embedded in the double-image technique. Indeed, the different visual layers of the painting (and of the flayed penises) figure irony itself, which according to Hutcheon relies on the superimposition of different levels of understanding:

Irony and parody [...] both operate on two levels, a primary surface level in the foreground, a secondary and implicit level in the background. This latter level, in both cases, extracts its meaning from context. The ultimate meaning of the ironic or parodic text resides in the superimposition of the two levels in a kind of double textual exposure (in the photographic sense of the term). (Hutcheon 1978, 472-473, my translation)

Furthermore, whereas male surrealists portrayed imaginary women from an outside perspective, Scylla is painted from the perspective of a real woman looking at herself in a bath. The painting places us in the position of a woman asserting her sexuality and her right to her own body. The boat that can be seen approaching the narrow oval gap can be interpreted as another phallic symbol. Colquhoun lets the viewer imagine her sexual penetration: she lays claim to her own sexual agency. In addition, the title of the painting trans-contextualizes the Homeric figure of Scylla, a female monster who 
inhabits narrow straits and devours sailors. This contributes to reinforcing the feminine and sexual character of the painting. ${ }^{6}$ Ferentinou has further commented that she sees in Colquhoun's adaptation of this powerful and relentless mythical figure a way for the artist to become Scylla herself (Ferentinou 2018, 179). Colquhoun then becomes a dangerous and enchanting female force within surrealism. She is able to create a liminal space where the vaginal and the phallic, the erotic and the menacing or monstrous coexist. She embodies and infuses new life into another image of femininity.

Colquhoun's fierce parodic impulse continued in 1939 with Gouffres Amers, ${ }^{7}$ a painting the primary focus of which seems to be male representation. Dawn Ades and Whitney Chadwick have suggested that, in Gouffres Amers, Colquhoun uses a technique similar to that of the sixteenth-century painter Giuseppe Arcimboldo, whose works were celebrated by members of the surrealist group and shown in surrealist exhibitions. ${ }^{8}$ "Arcimboldo created heads out of piled fruits, vegetables and so on, massing disparate objects until they melted into another form" (Ades 40). Here, corals and seaweeds assemble to compose a man's body. The naked man lies reclining on his side, dominating the rocky landscape in the background. Just as in Scylla, Colquhoun parodies the surrealist imagery that personifies natural forms as female. Here, by inversion, nature is male. Moreover, the male nude in Gouffres Amers is not an erotic object of desire and liberation. Whereas the naked female body in Roland Penrose's Good Shooting offers prospects of liberation and works as a gateway to undisturbed nature and imagination, Colquhoun's male nude does the opposite. It is not eroticized. The metamorphic process in Gouffres Amers does not lead to creation but to decay; the naked male body is that of a sea creature taken out of the water and left to putrefy in a hostile landscape.

16 The phrase "gouffres amers" originally appeared in Baudelaire's poem "The Albatross" in the Fleurs du Mal collection ("le navire glissant sur les gouffres amers" which translates in English as "the ship that slips through bitter gulfs"). It is here transcontextualized as the title of the painting. In Baudelaire's poem, the albatross is captured by sailors who torment it and strip it of its majesty. In the final stanza, the poet is compared to the albatross: once brought to earth, he is humiliated and rejected (Shillitoe 232). In the context of Colquhoun's painting, the male figure-possibly representing the male surrealist-is stripped of his worldly attire and left helpless. Colquhoun casts him aside as a figure that can be of neither help nor appeal for women and to which women artists should not look for realization. She refuses to provide a male equivalent to Scylla. It should, however, be noted that the condemnation and casting aside of the male surrealist is not fixed altogether, as the sprouting red flower and spreading leaves on the male nude suggest.

The rejection of eroticism as a transformative and inspiring force that would drive the surrealists in their redefinition of human consciousness initiated in the first two paintings is brought to its pinnacle in The Pine Family. ${ }^{9}$ In this painting, Colquhoun appropriates the surrealist technique of dismemberment and fragmentation, best exemplified in the works of Hans Bellmer. In a series of photographs entitled The Doll (1936), the German surrealist presents mutilated and partially dismembered life-sized dolls. In The Pine Family, three truncated bodies, which highly resemble tree trunks, lie next to each other. The label tied to the bodies tells us about their gender: the one at the bottom reads "celle qui boite" (she who limps) and is attached to the left thigh of the female; her right thigh has been amputated. The hermaphrodite body carries the 
label "l'hermaphrodite circoncis" (the circumcised hermaphrodite) around its right thigh; the penis has been sliced off while the vagina remains. The last body is male and bears the label "Atthis"; his penis has been severed.

Colqhoun's parody resides in the repeated reversal and trans-contextualization of surrealism's founding myths and obsessions. "Celle qui boite" is an ironical inversion of "celle qui avance" (she who advances), a phrase used by André Breton in the 1930s to describe Gradiva as the ideal woman. ${ }^{10}$ Gradiva was a mythical and literary figure whose name literally translates as "splendid in walking", and whom the surrealists turned into their archetypal muse. The surrealists believed she would lead them in "their unceasing attempt to glimpse what lies ahead, beyond the real" (Chadwick 419). As Ferentinou has previously shown (Ferentinou 2011, 14), literally turning her into "celle qui boite", Colquhoun disables the surrealist muse.

Another myth at stake in this painting is that of the hermaphrodite or androgyne. As mentioned before, several male surrealists incorporated the androgyne in their artistic practice, producing images endowed with sexual connotations, in which the male part is the main focus or takes over the female part. In The Pine Family, while offering a sexual portraying of the hermaphrodite, Colquhoun privileges the female part. The vagina has escaped mutilation and the body is labelled "l'hermaphrodite circoncis", a phrase Isidore Ducasse used in the nineteenth century to refer to the cross-dressing female writer George Sand. Finally, as Ferentinou remarks, the conjunction of androgyny, pine trees (in the title) and castration recalls the story of the Greek mythological figure Attis, who self-castrated behind a pine tree (Ferentinou 2011, 12). The male figure labelled "Atthis" therefore ironically undergoes the same dismembering as the others and completes Colquhoun's dark tally.

With this last painting, Colquhoun provides an incisive and derisive surrealist family portrait: as can be expected, the family is highly sexualized, the focus being on the lower part of the bodies and the name they bear being "pine", which is French slang for penis. However, and unlike in the two previous paintings, no phallus can be seen. In presenting such a doomed family, Colquhoun firmly parodies the phallocentrism prevalent in surrealism (Ferentinou 2011, 13). She also removes any surrealist female ideal from the picture and instead offers a predominantly vaginal landscape or "vaginal iconology" in the terms of Barbara Rose (Rose 575-577). Unlike in Scylla, Colquhoun does not depict an alternative feminine model but rather violently clears the way for women to find their own images and mythologies.

\section{Leonora Carrington's surrealistic parodies in The Hearing Trumpet}

While living in Mexico, removed from Breton's circle and from the turmoil of her years with Ernst, Carrington produced her parodic novel The Hearing Trumpet. While also addressing the archetypal representations of women within surrealism, Carrington's targets are slightly different from and strike a more personal chord than Colquhoun's. The novel is not a sustained parody of a specific surrealist text, but contains passages in which recognizable surrealist ideals and figures are parodied. Written in the 1950s but not published in English until 1976, The Hearing Trumpet recounts the adventures of Marian Leatherby, a 92-year-old English woman sent by her family to a Christian institution for old ladies. As the story unfolds, Marian and her fellow female residents 
rebel against the preaching and authority of the institution. This rebellion coincides with some major environmental disruptions that end up in a literal and symbolic decentering of the cosmos.

The novel is quite distinctly surrealist and has been described by critics as following surrealist codes and conventions (Aberth 59-60; O'Rawe 10; Smith xii-xv). Indeed, the novel has multiple narrators: besides Marian, no fewer than eight voices can be listed in The Hearing Trumpet. Some of them are heard via embedded narratives, letters or scrolls. This multi-vocality and the collage form it is articulated in undermine the cohesion of the narration. In addition, numerous passages in the novel depart from logic and reason. To give but a few examples, Carmella, Marian's best friend, always devises plans devoid of any rational sense to get her out of the retirement home, such as rescuing Marian with a helicopter won in a crossword puzzle competition (54). The pseudo-religious teachings and recommendations of the doctor at the head of the institution are similarly absurd and irrational: the doctor, for instance, advises that Marian, on her way to higher holy planes, stop eating cauliflower (46).

Carrington pokes fun at and parodies at least two surrealist ideals of femininity that she herself incarnated during her association with the movement: the first one is that of the femme-enfant or woman child. The figure of the woman child first appeared in a surrealist context in 1927 in the ninth issue of the journal La Révolution Surréaliste, edited by André Breton. On the front cover, an illustration depicts the woman child whom Chadwick has defined as "that enchanting creature who through her youth, naiveté, and purity possesses the more direct and pure connection with her own unconscious that allows her to serve as a guide for man" (33). This young woman is in a way predisposed for surrealism and serves as an intermediary between the male artist and creativity. This is of course reminiscent of the personal story of Carrington, who was drawn to surrealism by Ernst when she was only nineteen years old. Carrington was not the first woman child that Ernst had discovered and fallen in love with, and she herself feared that she might not be the last. ${ }^{11}$ In the preface that he wrote for one of Carrington's collections of short stories in 1938, Ernst declared that Carrington was his source of life, inspiration and admiration. ${ }^{12}$

In The Hearing Trumpet, Carrington playfully transforms the figure of the woman child by distorting her characteristic features. Carrington's approach is reminiscent of Michele Hannoosh's take on parody. Indeed, in Parody and Decadence, Hannoosh ascribes to parody a comic dimension, whether it be playful, such as is the case here, or ridiculing, as will be shown later with the treatment reserved for André Breton in the novel. ${ }^{13}$ Marian, the heroine of the novel, can be linked to the archetypal figure of the woman child since she has an intimate relationship with the world of childhood. She lives in a world of fantasy where she interacts with half-wolf, half-human creatures, and her adventures are punctuated by Lewis Carroll-like riddles, the answers to which are the key to the whole story. However, Marian is 92 years old and, it is precisely her old age, not her youth and innocence, that makes her a natural surrealist. Indeed, as an elderly lady, she is often tired and oscillates between slumbering and waking states: "Sleeping and waking are not quite as distinctive as they used to be, I often mix them up" (23). She literally and almost accidentally lives according to surrealist principles. While André Breton theorizes and intellectualizes this female ideal, Carrington mockingly deconstructs it by reducing her creative gifts to pathological features of senility. ${ }^{14}$ She presents a degraded version of his woman child. 
rrington goes further in her redefinition of the image of the woman child with the motif of the bearded woman. Marian, who describes herself in the first pages of the novel as having a gallant "short grey beard which conventional people would find repulsive" (3), is also the bearded abbess whose painting hangs in the retirement home, and Saint Barbara, the bearded hermaphrodite Goddess of the underworld. They are one and the same person; Marian possesses a complex and multi-faceted personality. She embodies gender fluidity as well as different forms of gendered power. This motif therefore configures her as a "polymorphous composite in flux" (Ferentinou 2018, 188), not a mediator or guide for any man, but a subject that discovers things for herself and continuously constructs herself. Marian, a bearded evasive crone, whom her grandson further describes as "hardly [...] a human being, [...] a drooling sack of decomposing flesh" (10), turns into a more desirable form of femininity.

Innocence and sexual appeal are discarded by Carrington as sources of creative transformation; madness and the archetype of the madwoman undergo a similar treatment in The Hearing Trumpet. The surrealists investigated madness, and more particularly female hysteria. In 1928, in the eleventh issue of La Révolution Surréaliste, Breton and Aragon redefined hysteria as a poetic precept: "hysteria is not a pathological phenomenon and can in every way be considered as a supreme means of expression". ${ }^{15}$ This was the year André Breton published Nadja, a novel that recounts his relationship with Nadja, a disturbed woman with clairvoyant powers. The freespirited but unpredictable woman portrayed by Breton instantly became the archetype of the madwoman for surrealism. In actual fact, their relationship was short-lived, as Breton could not cope with the realities of her life and her obsession with him. She was eventually institutionalized.

In The Hearing Trumpet, Natacha, a resident whose name is clearly evocative of Breton's femme folle, is a critical reworking of Nadja. ${ }^{16}$ Natacha is initially presented as a visionary with great powers: "She is controlled you understand, spiritual control is a rare and beautiful gift. Natacha is the Pure Vessel through which unseen powers are made manifest to us. 'NOT I BUT THAT WHICH WORKS WITHIN ME.' Those are Natacha's constant words" (38). However, several later incidents undermine Natacha's status and credibility. In one scene, while Marian is half asleep in the doctor's office, Natacha bursts in and reports her visions to the doctor. She declares that she received a message from The Great Beyond via a tall bearded man:

"You are The Pure Vessel through which the Will of the Master is made manifest to his flock. Rejoice for you are chosen to lead others, Natacha Blessed amongst women".

"Then", continued Natacha, gripping the chair and opening one eye, "he told me there was a message for Georgina Sykes. He said 'Tell Georgina Sykes that if she goes on spreading vicious gossip about Dr. Gambit and herself that her ever decreasing chances of Salvation will be petrified for ever"'.

I saw the Doctor twitch nervously. "What sort of gossip?" he asked sharply, then, modifying his tone to a hypnotic drawl, "What sort of gossip, Natacha?-you are blissfully calm and Serene-What sort of gossip?"

Natacha's voice was anything but blissfully calm and serene as she replied viciously: "You are going to get a nasty surprise about that backbiting, malignant old Trollop. Those sagging, baggy eyes of hers are going to ogle once too often". (48, my emphasis) 
Natacha then goes on to say that Georgina goes around telling people the doctor is sexually attracted to her. Natacha wants him to get rid of "that menace" (50) or she will leave the institution.

In a comical reversal of Breton's Nadja, the madwoman of Carrington's novel is a fraud. Indeed, Nadja's enchanting madness is transformed into an old woman's poorly staged performance. Natacha does not possess clairvoyant powers. She does not receive visions but rather constructs visions of her own, for she has understood that it is what the doctor desires. She uses madness as a strategy to manipulate the doctor into giving her what she wants. Later on, when the doctor fails to expel Georgina, Natacha tries to kill her, but mistakenly ends up poisoning another resident. The archetypal madwoman turns into a mediocre murderess. In that instance, Carrington's parody seems to be primarily playful. The author plays with the madwoman of Breton and denies the male character the possibility of deriving any creative inspiration or transformation from her (simulated) madness.

In another novel entitled Down Below, Carrington recounts the actual mental breakdown she went through before she fled from Europe in the early 1940s. The author is the madwoman herself and adopts an altogether different approach: madness is "a state in which women are afforded an insight into their real powers" (Ferentinou 2018, 183). In other words, the madwoman does not manipulate men to reverse power, but represents an alternative route to self-realization and empowerment. ${ }^{17}$

Finally, André Breton is ridiculed in The Hearing Trumpet. As previously mentioned, the doctor's relationship with Natacha ${ }^{18}$ recalls that of André Breton with Nadja. In her novel, Carrington critically portrays the doctor as naively relying on Natacha in the hope that she will reveal his destiny to him. Furthermore, the organization and doctrine of the doctor's institution mirror those of Breton's group. Indeed, the retirement home is described by Marian as unlike anything she had imagined (23): the residents live in separate bungalows, the design of which seems to have been inspired by dream visions. The residents are meant to adhere to a doctrine according to which they should relieve themselves of "interior impurities" (44) and "self-remember" (28), in other words explore and express their inner selves. In order to achieve this, they must perform group tasks as well as follow the doctor's individual recommendations. While the institution may at first seem unconventional, it is in fact ruled by a traditional power hierarchy. It is run by a single man who literally lives at the center of the property. The doctor seeks to control everything and needs to validate all activities. One of the characters remarks: "[Gambit is] [q]uite frightful and phoney as Hell. If one could get out of this dump he would cease to be important, being the only male around, you know. It is really too crashingly awful all these women. The place creeps with ovaries until one wants to scream" (33). In the end, "the doctor is representative of an old [hierarchy] of power that is sustained despite the novelty of the [movement] he promotes" (O'Rawe 191). Carrington offers a very satirical portrayal of the surrealist group. At the end of the novel, Dr. Gambit's institution and authority are overthrown and replaced with a "matriarchal anarchy" (Ferentinou 2018, 187), an alternative form of society where humans live freely at peace with their environment. 


\section{Concluding remarks: Colquhoun and Carrington's liberating engagement with parody}

31 Colquhoun's and Carrington's respective engagements with parody can first be read as responses to what they were experiencing in their artistic milieu. Parody represented an act of opposition and subversion as they playfully questioned and upset a surrealist ideology that held them in lesser positions. Parody was furthermore a means for them to insert themselves as subjects into surrealism. It meant that they initiated a dialogue within surrealism on its attitude towards women. Most important, it was also a liberating act which enabled Colquhoun and Carrington to investigate other, more encompassing, alternatives. Indeed, the two artists did not attempt to recreate the surrealist muse as an erotic image, but instead diversified the array of images of women in surrealism. Colquhoun's paintings presented a more assertive form of femininity. As for Carrington, she playfully established the crone or vieille femme as a more practical and accomplished example of femininity.

Both Colquhoun's paintings and Carrington's novel worked to overcome the gender disparities present in surrealism. They comically reworked archetypes of femininity, conflated male and female bodies and manipulated gender boundaries. In other words, Colquhoun and Carrington destabilized gender norms. In disrupting the basis of the artistic and social system they evolved in, they ultimately helped to pave the way for the construction of a new world.

\section{BIBLIOGRAPHY}

Aberth, Susan L. Leonora Carrington: Surrealism, Alchemy and Art. Farnham: Ashgate, 2004.

Ades, Dawn. "Notes on Two Women Surrealist Painters: Eileen Agar and Ithell Colquhoun". Oxford Art Journal 3.1 (1980): 36-42.

Allmer, Patricia (ed.). Angels of Anarchy: Women Artists and Surrealism. Munich: Prestel, 2009.

Breton, André. "Manifeste du surréalisme" (1924) and "Second manifeste du surréalisme" (1929). Euvres Complètes. Paris : Gallimard, 1988.

Breton, André. Nadja (1928). Paris: Gallimard, 1964.

Breton, André. Les Vases communicants (1932). Paris : Gallimard, 1955.

Breton, André and Paul Éluard. Dictionnaire abrégé du Surréalisme (1938). Paris : J. Corti, 1991.

Carrington, Leonora. La Maison de la peur. Paris : H. Parisot, 1938.

https://brbl-dl.library.yale.edu/vufind/Record/3558455 (last accessed 12 April 2020)

Carrington, Leonora. Down Below (1946). New York: New York Review Books, 2017.

Carrington, Leonora. The Hearing Trumpet (1976). London: Penguin Books, 2005.

Chadwick, Whitney. Women Artists and the Surrealist Movement. London: Thames \& Hudson, 1985. 
Colquhoun, Ithell. Scylla (1938). Tate Gallery, London.

Colquhoun, Ithell. Gouffres Amers (1939). Glasgow Hunterian Art Gallery, Glasgow.

Colquhoun, Ithell. The Pine Family (1940). Israel Museum, Jerusalem.

Colquhoun, Ithell. “The Mantic Stain”. Enquiry 2.4 (1949).

Colquhoun, Ithell. "Children of the Mantic Stain”. Athene 5.2 (1951).

Colquhoun, Ithell. "Letter of 9 June 1977". Dawn Ades, Michael Sweeney and Joanne Bernstein (eds.). Surrealism in the Tate Gallery Collection. Liverpool: Tate Gallery Liverpool, 1988.

Colvile, Georgiana M. M. “Temple of the Word. (Post-) Surrealist Women Artists' Literary Production in America and Mexico". Journal of Surrealism and the Americas 5.1-2 (2011).

Dalí, Salvador. “L'Âne pourri”. SASDLR 1 (July 1930).

Ferentinou, Victoria. "Ithell Colquhoun, Surrealism and the Occult". Papers of Surrealism 9 (2011). https://www.research.manchester.ac.uk/portal/files/63517393/surrealism_issue_9.pdf (last accessed 12 April 2020).

Ferentinou, Victoria. "The Quest for the Goddess: Matriarchy, Surrealism and Gender Politics in the Work of Ithell Colquhoun and Leonora Carrington". Tessel M. Bauduin, Victoria Ferentinou and Daniel Zamani (eds.). Surrealism, Occultism and Politics: In Search of the Marvellous. London/ New York: Routledge, 2018.

Garcia Ochoa, Gabriel. “The Hearing Trumpet: Leonora Carrington's Feminist Magical Realism”. COLLOQUY Text Theory Critique 20 (2010).

Gilbert, Sandra M. and Susan Gubar. The Madwoman in the Attic. New Haven/London: Yale UP, 1984.

Hannoosch, Michele. Parody and Decadence: Laforgue's Moralités légendaires. Columbus: Ohio State UP, 1989.

Hutcheon, Linda. A Theory of Parody: The Teachings of Twentieth-Century Art Forms. New York/ London: Routledge, 1991.

Hutcheon, Linda. "Ironie et parodie: stratégie et structure". Trans. Phillipe Hamon. Poétique 36 (1978).

Kaplan, Janet. Unexpected Journeys: The Art and Life of Remedios Varo. New York: Abbeville, 1988.

O'Rawe, Ricki. “'Should We Try to Self Remember While Playing Snakes and Ladders?' Dr. Gambit as Gurdjieff in Leonora Carrington's The Hearing Trumpet (1950)". Religion and the Arts 21 (2017): 189-208.

Rose, Barbara. "Vaginal Iconology". Hilary Robinson (ed.). Feminism-Art-Theory: An Anthology 19682000. Malden, MA: Blackwell Publishers, 2001.

Rose, Margaret. Parody/Meta-fiction. London: Croom Helm, 1979.

Rose, Margaret. Parody: Ancient, Modern, and Post-Modern. Cambridge: Cambridge UP, 1993.

Sangsue, Daniel. La Relation parodique. Paris: J. Corti, 2007.

Shillitoe, Richard. Ithell Colquhoun: Magician Born of Nature. Raleigh, North Carolina: Lulu Enterprises, 2009.

Smith, Ali. "Introduction". Leonora Carrington. The Hearing Trumpet. London: Penguin Books, 2005. 
Tate Gallery. Catalogue entry “Scylla”. Sept 2016.

http://www.tate.org.uk/art/artworks/colquhounscylla-t02140 (last accessed 12 April 2020).

Tran-Gervat, Yen-Mai. « Pour une définition opérationnelle de la parodie littéraire: parcours critique et enjeux d'un corpus spécifique ». Cahiers de Narratologie 13 (2006).

http://journals.openedition.org/narratologie/372 (last accessed 12 April 2020).

\section{NOTES}

1. Colquhoun wrote two essays on automatism, "The Mantic Stain" and "Children of the Mantic Stain". Victoria Ferentinou elaborates on the correspondences Colquhoun maintained with surrealist figures in "Ithell Colquhoun, Surrealism and the Occult" (Ferentinou 2011, 19).

2. "Asked about how they felt about the Surrealist identification of woman and muse, Leonora Carrington responded with a single word, 'bullshit', and Ithell colquhoun commented that 'Breton's vision of the "free and adored woman" didn't always prove a practical help for women, especially painters"” (Chadwick 66).

3. Gouffres Amers was removed from an art exhibition at Harrogate in 1941. Letters from the Harrogate Art Gallery Committee to Colquhoun explain that "your principal painting was not hung [...] the Art Gallery Committee refused to hang it on the grounds that it would cause protests in Harrogate". Richard Shillitoe also reports that Colquhoun was asked in 1942 to remove The Pine Family from the Leicester Galleries "because of its alleged pornographic content" (252).

4. Scylla, 1938, oil on canvas, $91.4 \times 61 \mathrm{~cm}$, Tate Gallery, London.

5. «La représentation d'un objet qui, sans la moindre modification figurative ou anatomique, soit en même temps la représentation d'un autre objet absolument différent, dénuée elle aussi de tout genre de déformation ou anormalité qui pourrait déceler quelque arrangement [...] Ces nouveaux simulacres menaçants agiront habilement et corrosivement avec la clarté des apparences physiques et diurnes » (Dalí 10-11).

6. Colquhoun herself reported that Scylla was "the nymph changed first into sea monster, then into rocks on the Italian side of the Straits of Messina and reputed dangerous to mariners" (Colqhoun 1988).

7. Gouffres amers, 1939, oil on canvas, 71.2 x $91.3 \mathrm{~cm}$, Glasgow Hunterian Art Gallery, Glasgow.

8. Fantastic Art, Dada and Surrealism at the Museum of Modern Art in New York in 1936 (Ades 40). Arcimboldo's works also appeared in the "presurrealist" section of the 1947 exhibition Le Surréalisme en 1947 organized by Breton and Duchamp in Paris.

9. The Pine Family, 1940, oil on canvas, 45.7 x $50.8 \mathrm{~cm}$, Israel Museum, Jerusalem.

10. Critics such as Chadwick, Shillitoe and Ferentinou put forward this interpretation and underlined Freud's great interest in this figure.

11. Carrington recounted later that she felt Ernst would one day replace her with another younger woman: "Once you were over 25 you were pretty well out" (Aberth 38 ).

12. Ernst admires her "intense life, mystery, her poetry". "She is a white cloud who brings life to nature" (Carrington 1938, 5-6).

13. Hannoosh talks about "the comical reworking and transformation of another text by distortion of its characteristic features" (10).

14. While it should be remembered that Carrington was in her thirties when writing the novel, the character of Marian can be construed as a form of self-parody (Colville 14, O'Rawe 199, Kaplan 95). Critics have also examined the character of Carmella as a parodic avatar of Remedios Varo, Carrington's fellow surrealist painter and close friend while in Mexico. 
15. As quoted in Chadwick (35). Originally in French: "L'hystérie n'est pas un phénomène pathologique et peut, à tous égards, être considérée comme un moyen suprême d'expression".

16. Gabriel Garcia Orchoa has previously analysed the character of Natacha in "The Hearing Trumpet: Leonora Carrington's Feminist Magical Realism".

17. Although Gilbert and Gubar do not mention Carrington's works in The Madwoman in the Attic, as they focus primarily on Victorian literature, their analysis is somehow in accord with what Carrington achieved in The Hearing Trumpet. She, indeed, repudiated the male version of the madwoman.

18. The doctor has also been analyzed by Ricki O'Rawe as a caricature or parody of Gurdjieff, the mystic who devised a method (The Fourth Way) for awakening one's consciousness.

\section{ABSTRACTS}

Parody and surrealism bring together British artists Ithell Colquhoun (1906-1988) and Leonora Carrington (1917-2011). As young artists in the 1930s, they both joined the surrealist avant-garde movement which aimed at revolutionizing human experience and offered great opportunities for female personal and artistic emancipation. This paper examines a selection of the works Colquhoun and Carrington produced in their prolific surrealist years-Scylla, Gouffres Amers, and The Pine Family for Colquhoun, and The Hearing Trumpet for Carrington-in order to show that the two artists parodied the gendered ideological assumptions underlying surrealism.

Les deux artistes britanniques Ithell Colquhoun (1906-1988) et Leonora Carrington (1917-2011) sont liées par le surréalisme et la parodie. Toutes deux jeunes artistes dans les années 1930, elles rejoignent les rangs du mouvement surréaliste qui a alors pour but de changer radicalement l'existence humaine et qui offre des perspectives d'émancipation aux femmes, tant au niveau personnel qu'au niveau artistique. L'étude de travaux surréalistes produits par Colquhoun et Carrington (Scylla, Gouffres Amers et The Pine Family de Colquhoun, et de The Hearing Trumpet de Carrington) montre que les deux artistes parodient les fondements idéologiques genrés qui soustendent le mouvement surréaliste.

\section{INDEX}

Mots-clés: surréalisme, parodie, genre

Keywords: surrealism, parody, gender

oeuvrecitee Scylla, Gouffres Amers, Pine Family (The), Hearing Trumpet (The)

\section{AUTHORS}

\section{TIFAINE BACHET}

Tifaine Bachet is a PhD student from the doctoral school of humanities and languages at The University of Tours, France. After having taught French at Heriot-Watt University in Edinburgh, Scotland, Tifaine returned to France in 2016 for a teaching fellow position in English at the 
University of Tours and began her research under the supervision of Professor Didier Girard. Her doctoral research focuses on the novels of British surrealist artist and occultist Ithell Colquhoun. 